\title{
Pengolahan Limbah Udang untuk Memperoleh Bahan Pakan Sumber Protein Hewani Pengganti Tepung Ikan
}

\author{
Shrimp Head Waste Processing to Obtain Feedstuffs \\ Sources of Animal Protein Fishmeal Substitutes
}

\author{
Mirzah $^{1}$ dan Filawati $^{2}$ \\ ${ }^{1}$ Jurusan Nutrisi dan Teknologi Pakan Fakultas Peternakan Universitas Andalas \\ Kampus Unand Limau Manis Padang 25163. Telp: 0751 72400, Fax. 0751 72400, \\ ${ }^{2}$ Fakultas Peternakan Universitas Jambi \\ e-mail: mirzah@faterna.unand.ac.id \\ (Diterima: 6 Desember 2012; Disetujui: 5 Februari 2013 )
}

\begin{abstract}
The objective of this study was to measure the effect of preparation the shrimp head waste to poultry feed. The experiment was conducted to examine the effect of soaking and steam heat treatment of shrimp heads waste (SHW) on nutrient and nutritional quality. The treatment is soaking and length of steam heat the shrimp heads waste. The experiment was designed in Completely Randomized Design, using factorial ( 3 $x 3)$ with three replication. The first factors was three level concentration of the dusk rice solution $(C 1=$ 10\%; $C 2=20 \%$; and C3 =30\%), and the second factors was length steam heat ( W1 = $30 \mathrm{~min} ; \mathrm{W} 2=45$ min; and W3 =60 min). Feed was soaked for 48 h prior to steam heat. The results showed that there was no interaction effects $(P>0.05)$ between concentration of the dusk rice solution and length of steam heat to dry matter (DM), crude protein (CP), lipid and fiber contents of SHW but length of steam factors was significant $(P<0.05)$ to dry matter, crude protein, lipid and fiber contents of SHW and digestibility coefficient (in-vitro) of crude protein. There were interactions $(P<0.01)$ concentration of the dusk rice solution and length of steam factors to chitin contents. There are no significant differences on metabolizable energy but nitrogen retention and protein digestibility was found to be significantly $(P<0.05)$ between the SHW processed than unprocessed. Based on comparative cost analyses and nutritive value indicated, the best treatment was filtered of the dusk rice solution with concentratin $20 \%$ and length of steam heat for 45 min.
\end{abstract}

Key word : Shrimp head waste, dusk rice solution, chitin, nutrient quality

\section{P E N D A H U L U A N}

Pakan merupakan faktor yang paling menentukan dalam usaha peternakan unggas, karena harga bahan pakan untuk ternak unggas relatif mahal dibandingkan dengan ternak ruminansia. Biaya yang dikeluarkan untuk bahan pakan (ransum) pada peternakan unggas merupakan biaya terbesar, yaitu berkisar 60 $70 \%$ dari seluruh biaya produksinya. Tepung ikan adalah bahan baku pakan yang menyebabkan mahalnya harga ransum unggas, karena tidak dapat dipenuhi dari produksi dalam negeri, sehingga lebih dari setengahnya, yaitu sebanyak 200 ribu ton/tahun kebutuhan tepung ikan Indonesia disuplai dari impor. Oleh sebab itu perlu bahan pakan alternatif sebagai pengganti tepung ikan ini, yaitu limbah udang (shrimp head waste).

Kementerian Kelautan dan Perikanan (2011) memprediksi produksi udang Indonesia pada periode 2010-2014 meningkat $74,75 \%$ atau menjadi 699 ribu ton, terdiri atas 500 ribu ton udang jenis Vaname (Litopenaeus vannamei) dan 199 ribu ton udang windu (Penaeus monodon). Apabila udang segar ini diolah menjadi udang beku, maka 35-70\% dari berat utuh akan menjadi limbah udang dalam bentuk kepala, kulit dan udang yang tidak layak konsumsi (Animal Feed Resuorces Information System, 2000). Mirzah (1997), 
menyatakan bahwa berat limbah udang ini adalah $44 \%$ dari berat utuh seluruh udang. Menurut beberapa penelitian, limbah udang mengandung protein kasarnya cukup tinggi, yaitu sebesar 45-55\% (Gernat, 2001; Odugawa et al., 2004; Panimo et al., 2004; Okaye et al., 2005: Khempaka et al., 2006). Namun demikian protein yang tinggi ini tidak dapat dimanfaatkan secara optimal oleh ternak unggas karena terdapatnya faktor pembatas, yaitu kandungan khitin yang tinggi, yaitu sebesar 30\% dari bahan keringnya (Purwaningsih, 2000).

Khitin merupakan suatu senyawa polisakarida struktural (seperti selulosa) yang mengandung nitrogen dalam bentuk N-Aceylated -glucosamin-polysacharida. Protein atau nitrogen yang ada pada limbah udang ini berikatan erat dengan khitin dan kalsium karbonatnya dalam bentuk komplek ikatan senyawa protein-khitin-kalsium karbonat, sehingga ketersediaannya (bioavailability) untuk dicerna oleh ternak unggas rendah, dan ternak unggas tidak cukup banyak mempunyai enzim khitinase pada saluran pencernaannya, sehingga tidak dapat menghidrolisis senyawa khitin ini.

Untuk meningkatkan kualitas dan pemanfaatan limbah udang secara maksimal dalam ransum, maka sebelum diberikan pada ternak perlu dilakukan pengolahan yang tepat, yaitu proses pengolahan yang dapat meningkatkan daya cerna dan dapat menurunkan kandungan khitinnya. Pengolahan secara kimiawi dengan menggunakan alkali $(\mathrm{NaOH})$ membantu dalam menghidrolisis protein yang terkandung dalam limbah industri dan pertanian. Larutan basa kuat $\mathrm{NaOH}$ merupakan alkali paling efektif dalam meningkatkan kecernaan limbah pertanian dan industri karena mampu membengkakkan ikatan lignoselulosa menjadi lebih besar sehingga kecernaannya meningkat (Soedjono dkk., 1985). $\mathrm{NaOH}$ mampu memperbesar volume partikel bahan (substrat), sehingga ikatan antar komponen menjadi renggang, juga mampu menghidrolisis gugus asetil pada khitin, sehingga khitin akan mengalami deasetilasi dan berubah menjadi khitosan yang menyebabkan kadar khitin berkurang (Suharto, 1984; Winarti, 1992)

Pengolahan dengan cara kimia yang mempunyai beberapa kelemahan terutama untuk pengolahan bahan baku pakan, yaitu proses yang menggunakan bahan kimia akan menyebabkan terjadinya pencemaran lingkungan, yaitu sisa bahan kimia ini bersifat polutan yang dapat meningkatkan BOD dan COD sungai. Disamping itu, bahan kimia yang masih tersisa pada bahan pakan juga menyebabkan efek kepada ternak dan juga pada konsumen. Salah satu alternatif pengganti bahan kimia tersebut, dapat digunakan bahan yang lebih ramah lingkungan, tidak bersifat polutan terhadap lingkungan dan tidak mempunyai efek terhadap ternak dan manusia yang mengkonsumsinya yaitu filtrat air abu sekam (FAAS) yang bersifat alkali dan banyak mengandung mineral-mineral oksida basa seperti $\mathrm{SiO}_{2} ; \mathrm{K} 2 \mathrm{O} ; \mathrm{Na}_{2} \mathrm{O} ; \mathrm{CaO} ; \mathrm{MgO} ; \mathrm{Fe}_{2} \mathrm{O}_{3}$ dan $\mathrm{SO}_{3}$ (Haryanto, 2002). Hasil pembakaran abu sekam mengandung silika sebagai komponen utamanya, dimana kandungan silika ini mencapai $86,90-97,30 \%$ basis kering (Houston, 1972 dalam Mirzah, 2004). Menurut Haryanto (2002) abu sekam padi berbentuk struktur sel (cellular structure), dengan banyak pori yang tertutup.

Perlakuan perendaman dengan filtrat air abu sekam (FAAS) dan dilanjutkan dengan pemanasan dengan cara pengukusan merupakan kombinasi perlakuan dalam proses pengolahan teknologi tepat guna yang mudah, murah, dan sederhana. Pembuatan filtrat air abu sekam (FAAS) sebagai larutan sebagai pengganti $\mathrm{NaOH}$ untuk perendam limbah udang dilakukan dengan cara sekam padi yang telah diabukan secara sempurna dilarutkan dalam air bersih. Kemudian untuk memperoleh larutan abu sekam padi $10 \%$ maka dilarutkan $100 \mathrm{~g}$ abu sekam padi dalam 900 liter air bersih. Larutan ini dibiarkan selama 24 jam, lalu disaring dan filtratnya disebut dengan filtrat air abu sekam. Untuk membuat FAAS $20 \%$ dan $30 \%$ dilakukan dengan cara yang sama (Mirzah, 2004).

Berdasarkan latar belakang di atas, perlu ditentukan kombinasi perlakuan antara kon- 
sentrasi filtrat air abu sekam dengan lamanya pemanasan menggunakan autoclav pada pengolahan limbah udang. Salah satu kombinasi perlakuan tersebut diharapkan dapat untuk mendegradasi senyawa protein-khitin-kalsium karbonatnya dengan maksimal. Selanjutnya juga perlu dievaluasi pengaruhnya terhadap kandungan nutrisi tepung limbah udang (TLU) dan kualitas nilai gizinya.

\section{MATERI DAN METODE}

Materi yang digunakan dalam penelitian ini adalah limbah udang yang diperoleh dari pasar tradisional Tanah Kongsi di kota Padang. Sebelum diolah limbah udang ini dibersihkan dari benda-benda asing yang melekat dan dicuci dengan air bersih. Bahan lain yang digunakan untuk merendam limbah udang adalah filtrat air abu sekam (FAAS). Pembuatan FAAS dilakukan dengan metode Mirzah (2004), dimana sekam padi yang telah diabukan secara sempurna dan dilarutkan dalam air bersih. Larutan abu sekam padi 10 $\%$ diperoleh dengan melarutkan $100 \mathrm{~g}$ abu sekam padi dalam 1 liter air bersih. Larutan ini dibiarkan selama 24 jam, lalu disaring untuk memperoleh filtratnya dan siap digunakan. Sementara FAAS $20 \%$ dan $30 \%$ dibuat dengan metode yang sama.

Perlakuan tahap pertama adalah perendaman limbah udang dalam botol kapasitas 1 $\mathrm{kg}$ dalam larutan filtrat air abu sekam (FAAS) dengan konsentrasi berbeda-beda selama 48 jam. Setelah direndam limbah udang ditiriskan dan kemudian dilanjutkan dengan pemanasan dengan cara autoclave dengan lama waktu yang berbeda. Percobaan ini dilakukan menggunakan Rancangan Acak Lengkap dengan susunan perlakuan pola Faktorial 3 x 3 dan dengan 3 ulangan (Steel dan Torri, 1991). Faktor pertama adalah tiga macam konsentrasi larutan FAAS yaitu $(\mathrm{K} 1=10 \%) ;(\mathrm{K} 2=20 \%)$ dan $(\mathrm{K} 3=30 \%)$, dan faktor kedua adalah 3 waktu pemanasan, yaitu diautoclave selama (W1 = 30 menit), (W2 = 45 menit), dan (W3 $=60$ menit).

Setelah pemanasan, kemudian limbah udang tersebut dikeringkan di bawah sinar matahari dan digiling menjadi tepung limbah udang olahan (TLUO) serta ditimbang beratnya. Selanjutnya dilakukan analisis proksimat (bahan kering, protein kasar, serat kasar, dan lemak kasar), serta kandungan khitinnya. TLUO terpilih didasarkan pada kandungan protein tertinggi dan khitin terendah. Selanjutnya TLUO terpilih diuji kualitas nutrisinya dengan menentukan nilai retensi nitrogen $(\mathrm{RN})$ dan energi metabolis (EM) menggunakan serta asam amino kritisnya (lisin, methionin dan triptophan).

Semua analisa kimia dilakukan dengan metode AOAC (1990) dan kandungan khitin menurut metode Hong (1983) dan atau Bastanan (1989). Kandungan asam amino ditentukan menggunakan alat HPLC, dimana sampel dihidrolisir selama 24 jam dalam ampul yang ditutup/berisi $6 \mathrm{~N} \mathrm{HCl}$ ada suhu $110^{\circ}$ $\mathrm{C}$, dan selanjutnya diinjet pada alat "thin layer chromatography". Di samping itu juga dilihat kualitas TLU olahan secara biologis (in-vivo) menggunakan ayam broiler jantan sebagai hewan percobaan untuk mengetahui energi termetabolis, retensi nitrogen dan daya cerna proteinnya. Energi metabolis dan retensi nitrogen menggunakan metode Sibbald (1980) dan Noy dan Sklan (1995) yang dimodifikasi sesuai kebutuhan, sedangkan kecernaan protein menurut metode Likuski dan Dorrell (1978), dan kecernaan protein secara in-vitro menurut metode Hand dan Parsons (1991).

\section{HASIL DAN PEMBAHASAN}

\section{Pengaruh Perlakuan terhadap Kandungan Nutrisi TLU Olahan}

Untuk menentukan kondisi-kondisi yang optimum dalam mempersiapkan atau preparasi limbah udang menjadi tepung limbah udang dilakukan dengan mengkombinasikan pengolahan secara kimia menggunakan FAAS dengan pengolahan secara fisik melalui pemanasan dengan autoclave. Rataan kandungan bahan kering, protein kasar, serat kasar, dan kandungan khitin masing-masing perlakuan ditampilkan pada Tabel 1.

Dari Tabel 1 dapat dilihat bahwa rataan kandungan zat-zat makanan TLU olahan de- 
ngan perendaman dalam larutan filtrat air abu sekam dengan konsentrasi 10\%, 20\% dan 30\% yang dikombinasikan dengan lama pemanasan 30 menit, 45 menit dan 60 menit tidak banyak berubah dibandingkan dengan kandungan zatzat makanan TLU tanpa diolah. Kandungan zat-zat makanan TLU tanpa diolah adalah sebagai berikut: kadar air 8,96\%; bahan kering 91.04\%; protein kasar 39,62\%; serat kasar 21,29\%; lemak kasar 5,43\%; abu 30,82\%; kalsium 15,88\%; phosfor $1,90 \%$ dan BETN 2,92\%. Sementara kandungan khitin TLU olahan adalah $10,55 \%$ dan nilai ini lebih rendah dibandingkan dengan TLU tanpa diolah sebesar $15,24 \%$. Kandungan khitin ini sangat dipengaruhi oleh proses pengolahan yang dilakukan.

Hasil penelitian secara umum menunjukkan bahwa semakin tinggi konsentrasi larutan FAAS dan semakin lama waktu pemanasan maka semakin menurun kandungan bahan kering, protein kasar, serat kasar, lemak kasar dan kandungan khitin TLU olahan. Tidak terjadi interaksi yang nyata $(\mathrm{P}>0,05)$ antara konsentrasi larutan FAAS dengan lama pemanasan limbah udang terhadap nilai gizi TLU olahan, kecuali pada kandungan khitin terdapat interaksi yang sangat nyata $(\mathrm{P}<0,05)$.

Peningkatan konsentrasi FAAS tidak berpengaruh nyata $(\mathrm{P}>0,05)$ pada kandungan bahan kering, namun faktor lama waktu pemanasan limbah udang memberikan pengaruh berbeda sangat nyata $(\mathrm{P}<0,01)$ pada kandungan bahan kering. Pada protein kasarnya, peningkatan konsentrasi larutan FAAS dan lama pemanasan memberikan pengaruh nyata $(\mathrm{P}<0,05)$ terhadap penurunan kandungan protein kasar. Pada Tabel 1 juga menunjukkan peningkatan konsentrasi larutan FAAS tidak memberikan pengaruh yang nyata pada kandungan serat kasar, namun faktor lama pemanasan sangat nyata $(\mathrm{P}<0,01)$ menurunkan kandungan serat kasar. Pada kandungan lemak TLU olahan, terlihat bahwa faktor peningkatan konsentrasi larutan FAAS dan lama waktu pemanasan serta interaksinya tidak menunjukkan pengaruh yang nyata $(\mathrm{P}>0,05)$ terhadap kandungan lemak kasar TLU hasil olahan. Begitu juga pada kandungan kalsium dan phosfornya, peningkatan konsentrasi peningkatan konsentrasi larutan FAAS dan lamanya waktu pemanasan serta interaksinya tidak menunjukkan pengaruh yang nyata $(\mathrm{P}>0,05)$ terhadap kandungan kalsium dan phosfor. Namun terlihat ketidak konsistennya kalsium dan phosfor ini pada setiap kombinasi perlakuan yang ada. Hal ini lebih disebabkan oleh perbedaan konsentrasi FAAS, karena larutan FAAS ini banyak mengandung oksida basa. Menurut Houston (1972) dalam Mirzah (2004), komposisi kimia filtrat air abu sekam mengandung beberapa mineral, yaitu oksida K 0,58-2,5\%; oksida Na 1,75\%; oksida Ca $0,2-1,5 \%$; oksida Mg 0,12-1,96\%, sedangkan hasil analisis Lab. Gizi Ruminansia Unand (2000), kandungan oksida $\mathrm{Ca}$ 8,80\% dan oksida P $0,92 \%$.

Kandungan khitin TLU hasil olahan pada penelitian ini sangat dipengruhi oleh faktor konsentrasi larutan FAAS dan lama waktu pemanasan. Terdapat interaksi yang sangat nyata $(\mathrm{P}<0,01)$, dimana semakin tinggi konsentrasi larutan FAAS dan semakin lama waktu pemanasan makan semakin menurun kandungan khitin. Hasil penelitian menunjukkan bahwa rataan penurunan kandungan khitin adalah sebesar lebih kurang 34\% dibandingkan kandungan khitin limbah udang tanpa diolah. Hasil hampir sama yang didapat oleh Palupi (2005), bahwa penurunan kandungan khitin yang diolah dengan larutan FAAS 10\% dan dikukus selama 45 menit adalah sebesar $33,40 \%$.

Terjadinya penurunan dari bahan kering lebih banyak disebabkan adanya proses perendaman yang mengakibatkan terlarutnya sebagian zat-zat makanan yang larut dalam air seperti vitamin, karbohidrat dan protein yang mudah larut, pigmen astaxanthin serta sebagian lemak yang turun pada waktu pemanasan dengan autoclave, sehingga akan menurunkan kandungan bahan keringnya dibandingkan TLU tanpa diolah. Di samping itu, waktu pengukusan yang lama juga mengubah kadar air bahan pakan sehingga akan mempengaruhi bahan kering produk TU olahan. Waktu pengukusan yang makin lama dalam pengolahan akan berakibat semakin banyak terjadi 
Tabel 1. Rataan Kandungan Nutrisi dan Khitin TLU Olahan dengan FAAS (\%)

\begin{tabular}{|c|c|c|c|c|c|}
\hline \multirow{3}{*}{ Zat Makanan } & \multirow{3}{*}{$\begin{array}{l}\text { Lama } \\
\text { Pemanasan } \\
\text { (menit) }\end{array}$} & \multirow{2}{*}{\multicolumn{3}{|c|}{ Konsentrasi F A A S }} & \multirow{3}{*}{ Rataan } \\
\hline & & & & & \\
\hline & & K $10 \%$ & K $20 \%$ & K $30 \%$ & \\
\hline \multirow{3}{*}{ Bahan Kering } & W 30 & 91,29 & 90,23 & 89,34 & 90,29 \\
\hline & $\mathrm{W} 45$ & 91,79 & 90,01 & 89,40 & 90,40 \\
\hline & W 60 & 91,16 & 91,60 & 90,38 & 91,05 \\
\hline \multirow[t]{2}{*}{ Rataan } & & $91,41^{\text {a }}$ & $90,61^{\mathrm{a}}$ & $89.71^{b}$ & 90,58 \\
\hline & W 30 & 40,64 & 40,49 & 39,27 & $40,13^{\mathrm{a}}$ \\
\hline Protein & W 45 & 40,21 & 42,23 & 39,48 & $40,64^{b}$ \\
\hline Kasar & W 60 & 39,93 & 41,98 & 37,85 & $39,92^{\mathrm{a}}$ \\
\hline \multirow{2}{*}{ Rataan } & & $40,26^{\mathrm{b}}$ & $41,57^{\mathrm{c}}$ & $38,86^{\mathrm{a}}$ & 40,23 \\
\hline & W 30 & 19,91 & 20,12 & 20,01 & $20,01^{\mathrm{a}}$ \\
\hline Serat & W 45 & 19,97 & 19,87 & 18,71 & $19,52^{\mathrm{a}}$ \\
\hline Kasar & W 60 & 19,08 & 18,50 & 18,29 & $18,62^{b}$ \\
\hline Rataan & & 19,65 & 19,49 & 19,00 & 19,38 \\
\hline \multirow[t]{3}{*}{ Lemak } & W 30 & 3,11 & 3,68 & 3,18 & 3,32 \\
\hline & W 45 & 3,31 & 2,89 & 3,05 & 3,08 \\
\hline & W 60 & 3,05 & 2,83 & 3,06 & 2,98 \\
\hline \multirow[t]{2}{*}{ Rataan } & & 3,16 & 3,13 & 3,10 & 3,66 \\
\hline & W30 & 14,68 & 14,49 & 13,23 & 14,13 \\
\hline \multirow[t]{2}{*}{ Kalsium } & W45 & 14,02 & 13,23 & 13,45 & 13,57 \\
\hline & W60 & 12,93 & 12,98 & 12,83 & 12,91 \\
\hline \multirow[t]{2}{*}{ Rataan } & & 13,88 & 13,57 & 13,17 & 13,54 \\
\hline & W30 & 2,79 & 2,12 & 2,61 & 2,51 \\
\hline \multirow[t]{2}{*}{ Phosfor } & W45 & 2,64 & 2,08 & 2,71 & 2,48 \\
\hline & W60 & 2,68 & 2,50 & 2,29 & 2,49 \\
\hline \multirow[t]{2}{*}{ Rataan } & & 2,70 & 2,23 & 2,54 & 2,49 \\
\hline & W30 & $12,87^{\mathrm{Aa}}$ & $10,18^{\mathrm{Ab}}$ & $10,11^{\mathrm{Ab}}$ & $11,05^{\mathrm{a}}$ \\
\hline \multirow[t]{2}{*}{ Khitin } & W45 & $12,27^{\mathrm{Aa}}$ & $9,56^{\text {В b }}$ & $9,27^{\mathrm{B} \mathrm{c}}$ & $10,37^{\mathrm{b}}$ \\
\hline & W60 & $11,90^{\mathbf{B} \mathbf{a}}$ & $9,35^{\mathrm{Bc}}$ & $9,48^{\text {в } ~}$ & $10,27^{\mathrm{b}}$ \\
\hline Rataan & & $12,35^{\mathrm{a}}$ & $9,70^{b}$ & $9,62^{b}$ & 10,55 \\
\hline
\end{tabular}

Keterangan : ${ }^{\mathrm{abc}}$ berbeda pada baris menunjukkan pengaruh yang berbeda nyata $(\mathrm{P}<0,05) .{ }^{\mathrm{ABC}}$ berbeda pada kolom menunjukkan pengaruh yang berbeda nyata $(\mathrm{P}<0,05)$

hidrolis, sehingga menurunnya kandungan air produk. Menurut Winarno dkk. (1980); Lee dan Garlich ( 1992) dan Latshaw et al. (1994), penurunan kadar air pada pengolahan dengan uap akan diikuti dengan meningkatnya jumlah atau persentase bahan kering, sehingga akan merubah nilai zat-zat makanan lainnya seperti protein kasar, serat kasar, dan lemak serta BETN. Dapat dikatakan bahwa terjadinya perubahan baik meningkat maupun menurunnya kandungan zat-zat makanan lebih banyak disebabkan berubahnya kandungan bahan kering TLU olahan ini.

Hasil yang diperoleh pada penelitian ini tidak jauh berbeda dengan hasil penelitian oleh Filawati (2003), yaitu kandungan zat-zat makanan pada limbah udang yang diolah dengan direndam dalam larutan kimia dan se- lanjutnya dipanaskan dengan cara dikukus (proses fisiko-kimia), menunjukkan bahwa faktor jenis larutan tidak memberikan pengaruh yang nyata, sedang waktu pengukusan memberikan pengaruh nyata terhadap kandungan zat makanan. Sesuai dengan penelitian Mirzah (1997) bahwa pemanasan dengan autoclave tidak banyak merubah komposisi zat-zat makanan pada limbah udang, kecuali pada kualitas nutrisi zat-zat makanan akan meningkat terutama kecernaan protein dan retensi nitrogen serta kandungan khitinnya.

Berdasarkan nilai nutrisi dan kandungan khitin pada penelitian ini yang menjadi dasar untuk mendapat perlakuan dalam proses pengolahan limbah udang (preparasi) yaitu kandungan protein tertinggi dan kandungan khitin yang terendah, maka yang terpilih ada- 
lah produk TLU yang diolah dengan perendaman dalam larutan FAAS konsentrasi 20\% dengan lama pemanasan 45 menit, yaitu dengan nilai gizi kadar air 9,39\%, bahan kering $90,61 \%$, protein kasar $42,23 \%$, serat kasar $19,87 \%$, lemak kasar 2,89\% dan kandungannya khitinnya sebanyak $9,56 \%$.

\section{Kualitas Nutrisi TLU Olahan Terpilih}

Untuk mengevaluasi nilai gizi dari TLU olahan terpilih maka lebih lanjut diuji kualitas nilai nutrisinya meliputi nilai retensi nitrogen, energi metabolis dan kecernaan protein kasarnya dan dibandingkan dengan kualitas nutrisi TLU tanpa diolah. Hasilnya disajikan pada Tabel 2.

Pada Tabel 2 dapat dilihat bahwa rataan retensi nitrogen, energi metabolis dan kecernaan protein kasar (in-vitro) berturut-turut sebesar 55,90\%, $1952 \mathrm{kkal} / \mathrm{kg}$ dan 57,25\% pada TLU tanpa diolah, sedangkan rataan retensi nitrogen, energi metabolis dan kecernaan protein kasar secara in-vitro berturutturut sebesar $62,20 \%, 1958 \mathrm{kkal} / \mathrm{kg}$ dan $78,53 \%$. Uji t menunjukkan bahwa nilai retensi nitrogen dan kecernaan protein kasar pada TLU tanpa diolah berbeda nyata $(\mathrm{P}<$ 0,05 ) lebih rendah dibandingkan dengan TLU olahan terpilih dengan FAAS $20 \%$ dan lama pemanasan 45 menit. Kecuali nilai energi metabolis antara kedua TLU tanpa diolah de- ngan TLU olahan terpilih tidak berbeda nyata. TLU olahan dengan FAAS $20 \%$ dengan lama pemanasan 45 menit, yaitu sebesar 1.958 $\mathrm{kkal} / \mathrm{kg}$, dan tidak berbeda dengan TLU tanpa diolah sebesar $1.952 \mathrm{kkal} / \mathrm{kg}$.

Nilai retensi nitrogen pada Tabel 2 menunjukkan hasil berbeda dengan nilai energi metabolis. Nilai retensi nitrogen pada TLU tanpa diolah lebih rendah yaitu $55,90 \%$, sedangkan TLU yang diolah dengan FAAS $20 \%$ dengan pemanasan selama 45 menit, yaitu sebesar $62,20 \%$. Dari uji t, terlihat retensi nitrogen TLU yang diolah dengan FAAS 20\% dengan pemanasan 45 menit berbeda nyata $(\mathrm{P}<0,05)$ lebih besar dibandingkan dengan TLU tanpa diolah. Lebih tingginya retensi nitrogen TLU olahan disebabkan proses perendaman dengan FAAS 20\% dan panas serta oksida basa dari FAAS yang diberikan dapat merenggangkan ikatan senyawa proteinkhitin-kalsium karbonat pada limbah udang ini, sehingga banyak asetil amino yang terlepas dari ikatan $\beta(1,4)$ glikosidik khitin pada limbah udang.

Kecernaan protein kasar (in-vitro) pada TLU hasil olahan dengan FAAS 20\% seperti terlihat pada Tabel 2 menunjukkan adanya peningkatan yaitu dari $57,25 \%$ pada TLU tanpa diolah menjadi 78,53\%.

Kecernaan protein kasar limbah udang yang diolah dengan FAAS 20\% lebih tinggi

Tabel 2. Nilai Retensi nitrogen, Energi Metabolis dan Kecernaan Protein TLU Olahan Terpilih Dibandingkan dengan TLU Tanpa Diolah

\begin{tabular}{|c|c|c|c|c|c|c|}
\hline \multirow{3}{*}{ No. } & \multicolumn{6}{|c|}{ Tepung Limbah Udang } \\
\hline & \multicolumn{3}{|c|}{ TLU Tanpa Diolah } & \multicolumn{3}{|c|}{$\begin{array}{c}\text { TLU Olahan dengan FAAS } 20 \% \\
\text { dan pemanasan } 45 \text { menit }\end{array}$} \\
\hline & $\begin{array}{l}\mathrm{R} \mathrm{N} \\
(\%)\end{array}$ & $\begin{array}{c}\text { E M } \\
(\mathrm{Kkal} / \mathrm{kg})\end{array}$ & $\begin{array}{c}\text { Kecernaan } \\
\text { PK in-vitro } \\
(\%)\end{array}$ & $\begin{array}{l}\mathrm{R} \mathrm{N} \\
(\%)\end{array}$ & $\begin{array}{c}\mathrm{E} \mathrm{M} \\
(\mathrm{Kkal} / \mathrm{kg})\end{array}$ & $\begin{array}{c}\text { Kecernaan } \\
\text { PK in-vitro (\%) }\end{array}$ \\
\hline 1 & 56,61 & 1880 & 57,71 & 63,23 & 1830 & 77,89 \\
\hline 2 & 57,18 & 2019 & 57,06 & 62,93 & 1971 & 79.32 \\
\hline 3 & 55,79 & 1999 & 58.48 & 60,02 & 1927 & 78,61 \\
\hline 4 & 53,16 & 1969 & 55.91 & 62,76 & 2060 & 77,92 \\
\hline 5 & 54,63 & 1952 & 57,98 & 61,98 & 2007 & 78,54 \\
\hline 6 & 58.03 & 1895 & 56,34 & 62,25 & 1958 & 78,87 \\
\hline Rataan & $55,90^{\mathrm{a}}$ & $1952^{a}$ & $57,25^{\mathrm{a}}$ & $62,20^{b}$ & $1958^{a}$ & $78,53^{b}$ \\
\hline
\end{tabular}


dibandingkan dengan TLU tanpa diolah. Kecernaan protein yang tinggi ini disebabkan oleh adanya kombinasi perlakuan secara kimia dan fisik (fisiko-kimia). Menurut Mirzah (1997), pengolahan limbah udang secara fisik menggunakan autoclave pada tekanan 3 $\mathrm{kg} / \mathrm{cm}^{2}$ selama 45 menit dapat meningkatkan kecernaan protein TLU dari 50\% menjadi $72 \%$. Peningkatan kecernaan protein kasar ini juga tidak terlepas dari pengaruh menurunnya kandungan khitin dari TLU olahan. Preparasi yang dilakukan secara fisiko-kimia pada limbah udang juga berpengaruh besar terhadap kecernaan protein kasar, karena ikatan komplek antara khitin-protein-kalsium karbonat telah direnggangkan, sehingga akan memudahkan degradasi asam dan pepsin secara in-vitro terhadap substrat.

\section{Kandungan Asam Amino TLU Olahan}

Hasil pengolahan terpilih berdasarkan kandungan zat-zat makanan secara proksimat dilakukan diuji juga kandungan asam-asam aminonya. Kandungan asam-asam amino TLU olahan terpilih dibandingkan TLU tanpa diolah disajikan pada Tabel 3.
Tabel 3 menunjukkan bahwa kandungan asam-asam amino TLU olahan sedikit lebih rendah dibandingkan dengan TLU sebelum diolah. Namun dibandingkan dengan tepung ikan, maka TLU mempunyai kadar asam amino jauh lebih rendah. Penurunan kadar asam amino TLU olahan disebabkan proses pengolahan dengan cara perendaman dalam larutan FAAS dan dan dipanaskan, maka sebagian asam aminonya akan larut dalam larutan FAAS dan selanjutnya mengalami pencucian (leaching) dan hanyut bersama cairan FAAS. Namun banyak diketahui bahwa beberapa asam amino tertentu dapat mengalami kerusakan (degradasi) atau perubahan dalam kondisi hidrolisis pada waktu pengolahan dengan panas dan juga pada waktu preparasi sample untuk dianalisis. Besar kecilnya degradasi selain disebabkan panas pada waktu pengolahan juga disebabkan faktor zat-zat makanan lain (karbohidrat, lemak dan mineral), bahkan adanya interaksi antar asam amino itu sendiri. Perubahan yang terjadi pada kandungan asam amino pada limbah udang bisa disebabkan memang oleh perlakuan tetapi tidak tertutup kemungkinan oleh proses degradasi.

Tabel 3. Kandungan Asam-asam Amino TLU Olahan (\%)

\begin{tabular}{lccc}
\hline \multirow{2}{*}{ Asam- amino } & \multicolumn{3}{c}{ Tepung Limbah Udang } \\
\cline { 2 - 4 } & TLU Tanpa Diolah (\%) & $\begin{array}{c}\text { TLU FAAS 20\% dan } \\
\text { menit }\end{array}$ & Tepung Ikan $(\%)^{1}$ \\
\hline Metionin & 1.16 & 0.93 & 1,30 \\
Cystin & 0.65 & 0.54 & 0,53 \\
Lysin & 0.42 & 0.35 & 3,97 \\
Threonin & 2.04 & 1.97 & 2,25 \\
Tryptopan & 0.53 & 0.38 & 0,45 \\
Arginin & 2.55 & 2.33 & 3,19 \\
Isoleusin & 1.51 & 1.25 & 2,26 \\
Leusin & 2.53 & 1.80 & 3,78 \\
Valin & 2.00 & 1.86 & 2,79 \\
Histidin & 0.36 & 0.27 & 1,42 \\
Phenilalanin & 1.70 & 1.70 & 2,44 \\
Tyrosin & 0.42 & 0.54 & 1,82 \\
Glysin & 0.69 & 0.59 & 4,04 \\
Serin & 1.72 & 1.13 & - \\
Prolin & 0.74 & 0.66 & - \\
Alanin & 0.70 & 0.62 & - \\
Aspartat & 3.35 & 2.83 & - \\
Glutamat & 4.40 & 4.28 & - \\
\hline Ken & & &
\end{tabular}

Keterangan : 1) Hartadi dkk (1990) 
Berdasarkan bentuk fisik TLU olahan tidak berbeda dengan TLU tanpa diolah, kecuali pada bau, TLU tidak diolah baunya lebih menyengat dibandingkan yang diolah. Begitu juga pada warna, TLU yang diolah warnanya lebih pucat dibandingkan TLU tanpa diolah. Hal ini disebabkan pigmen astaxanthin sudah banyak yang larut dan hilang pada waktu proses fermentasi. Dari hasil penelitian secara keseluruhan, maka diperoleh satu kombinasi perlakuan dalam pengolahan limbah udang ini, yang menghasilkan produk TLU olahan terpilih yang dapat diaplikasikan pada susunan ransum ternak unggas sebagai bahan pakan sumber protein hewani alternatif pengganti tepung ikan. Perlakuan terpilih adalah pengolahan dengan cara perendaman dalam larutan FAAS $20 \%$ selama 48 jam dan dipanaskan dengan autoclave selama 45 menit. Kandungan gizi dan kualitas nutrisi TLU olahan terpilih adalah protein kasar 42,23\%; serat kasar 19,87\%; lemak 2,89\%; kalsium 13,23\%; phosfor 2,08\%; kandungan khitin 9,56\%; kecernaan protein kasar (in-vitro) 78,53\%; dan energi metabolis sebesar $1.958 \mathrm{kkal} / \mathrm{kg}$ serta retensi nitrogen $66,20 \%$, dan kandungan asam amino kritis seperti metionin sebesar $0,93 \%$; lysine $0,35 \%$ dan triptophan $0,38 \%$.

\section{KESIMPULAN}

Pengolahan limbah udang dengan pemberian praperlakuan dengan cara perendaman dalam larutan filtrat air abu sekam (FAAS) 20 $\%$ selama 48 jam dan dipanaskan dengan autoclave selama 45 menit dapat memperbaiki kualitas nilai nutrisinya dibandingkan TLU tanpa diolah. Kandungan gizi dan kualitas nutrisi TLU olahan terpilih adalah protein kasar 42,23\%; serat kasar 19,87\%; lemak 2,89\%; kalsium 13,23\%; phosfor 2,08\%; kandungan khitin 9,56\%; kecernaan protein kasar (in-vitro) 78,53\%; dan energi metabolis sebesar $1.958 \mathrm{kkal} / \mathrm{kg}$ serta retensi nitrogen $66,20 \%$, dan kandungan asam amino kritis seperti metionin sebesar $0,93 \%$; lysine $0,35 \%$ dan triptophan $0,38 \%$.

\section{DAFTAR PUSTAKA}

A.O.A.C. 1990. Official Methods of Analysis, $15^{\text {th }}$ Ed. A.O.A.C.., Arlington, Vol. II, 1990: a) Method 988.15, Tryptophan in Foods and Feed Ingredients, p.1101. b) Method 985.28, Sulfur Amino Acids in Foods and Feed Ingredients, p.1102.

Bastaman, S. 1989. Studies on Degradation and Extraction of Chitin and Chitosan from Prawn Shells. Thesis the Queen's University of Belfast, Irlandian

Palupi, R. 2005. Pengaruh lama pengukusan limbah udang yang direndam dengan filtrat air abu sekam terhadap kualitas limbah udang dan pemanfaatannya pada ayam broiler. Tesis. Program Pascasarjana Universitas Andalas, Padang

Fanimo, A.O, O.O. Oduguwa, B.O. Oduguwa, O.Y. Ajas and O. Jegede. 2004. Feeding value of shrimp meal for growing pig, hhtp://.uco.es/organiza.

Filawati. 2003. Pengolahan Limbah Udang Secara Fisika-kimia dan Pengaruh Pemanfaatannya dalam Ransum Terhadap Penampilan Produksi ayam Petelur. Thesis, Program Pascasarjana Univesitas Andalas, Padang.

Gernat, A.G. 2001. The effect of using different level of shrimp meal in laying hen diet. Research Note. Poultry Science 80: $633-636$.

Hand, Y and C.M. Parsons. 1991. Protein and amino acid quality of feather meals. Oultry Science. 70: $812-822$

Hartadi, H., S. Reksohadiprodjo dan A.D. Tillman. 1990. Tabel Komposisi Pakan untuk Indonesia. Cetakan 
Ketiga. Gadjah Mada University Press, Yogyakarta.

Haryanto, B. 2002. Bahan bakar alternatif biodiesel. Journal Universitas Sumatera Utara. Medan.

Hong, K.N., S.P. Mayers and K.S. Lee. 1989. Isolation and characterization of chitin from crawfish shell waste. Journal of Agricultural and Food Chemistry. 37.

Josupeit, H. 2004. An overview on the world shrimp market. GLOBEFISH, Food and Agriculture Organisation of the United Nation. http://www.globefish. org

Kementerian Perikanan dan Kelautan. 2011. Potensi Limbah Udang di Indonesia menjadi Khitosan. Laporan Tahunan DPK, Jakarta.

Khempaka, S., K. Koh and Y. Karasawa. 2006. Effect of shrimp meal on growth performance and digestibility in growing broiler. J. Puoltry Sci., 43: $250-254$.

Latshaw, J.D., N. Musharaf and R. Retrun. 1993. Processing of feather meal to maximize its nutritional value for poultry. Animal Feed Sci and Tech. 47: $179-188$.

Likuski, H.J.H., and H.G. Dorrell. 1978. A bioassay for rapid determination of amino acid availability value. Poultry Sci. 57 : 1658-1660.

Lee , H and J.D. Garlich. 1992. Effect of overcooked soybea meal on chicken performance and amino acid availability. Poultry Science 71: 499 508.

Mirzah. 1997. Pengaruh Pengolahan Tepung Limbah Udang Dengan Tekanan Uap Panas terhadap Kualitas dan Peman- faatannya Dalam Ransum Ayam Broiler. Disertasi, Program Pascasarjana. Universitas Padjadjaran, Bandung.

Mirzah. 2004. Peningkatan Bioavailability Limbah Udang Melalui Pengolahan dan Pemanfaatnynya Sebagai pakan Pengganti Tepung Ikan Dalam Ransum Ternak Unggas. Laporan Penelitian Universitas Andalas, Padang

Noy, Y. and D. Sklan. 1995. Digestion and absorption in the young chick. Poultry Sci. 74: 366 - 373.

Oduguwa, O.O., A.O. Fanimo, V.O. Olayemi and N. Oteri. 2004. The feeding value of sun-dried shrimp-waste meal based diets for starter and finisher broilers. Archivos de Zootecnia, 53: 87-90.

Okaye, F.C., G.S. Ojewola, and K. NjokuOnu. 2005. Evaluation of shrimp waste meal as a probable animal protein source for broiler chicken. International Journal of Poultry Science 12: 456 - 461 .

Purwaningsih, S. 2000. Teknologi Pembekuan Udang, Penebar Swadaya, Jakarta.

Sibbald, I.R.. 1980. Metabolizable energy evaluation of poultry diets. In: Recent Advances in Animal Nutrition. W. Haresign and D. Lewis Eds. London, Butterworth.

Soedjono, M., R. Utomo dam S.P.S. Budhi. 1985. Pengaruh Perlakuan Alkali Terhadap Kecernaan In Vitro Bagasse. Proceeding Seminar Pemanfaatan Limbah Tebu untuk Pakan Ternak. Pusat Penelitian Pengembangan Peternakan, Badan Penelitian dan Pengembangan Pertanian Departemen Pertanian, Bogor. 
Steel, R.G.D., And J.H. Torrie. 1991. Prinsip Dan Prosedur Statistika, Suatu Pendekatan Biometrik. P.T. Gramedia Pustaka Utama, Jakarta.

Winarno, F.G dan D. Fardiaz. 1980. Penangan Teknologi Pangan. PT. Gramedia, Jakarta.
Winarti, R. 1992. Pengaruh konsentrasi $\mathrm{NaOH}$ dan Waktu Deasetilasi Khitin Terhadap Pembentukan Khitosan. Skripsi S1. Fakultas Teknologi Pertanian Universitas Gadjah Mada, Yogyakarta. 